\title{
WASATHIYYAH ISLAM AS THE ROAD TO MODERATISM IN INDONESIA
}

\author{
Abdurrohman Kasdi \\ IAIN Kudus \\ Email: abdurrohmankasdi@iainkudus.ac.id
}

\begin{abstract}
The article aims to explore the implementation of al-wasathiyyah concept as a way towards achieving moderatism, as well as to see the discourse of Islam and moderation in Indonesia. The method is qualitative with religious sociological approach. Religious sociological approach is used because the wasathiyyah concept is tightly tied to the religion and society. The results of the research show that wasathiyyah Islam has the correlation to ethics and moderate traditions which are considered as a form of virtue. Moderate tradition in Islam in Indonesia includes several aspects of life, including: first, moderate in its thought and movement, which is reflected by the belief that is in line with the nature and ibadah that promotes world prosperity. Second, moderate in aqidah that is in line with the fitrah or nature of mankind, including in tolerance, consistence, and balance. Third, moderate in practicing Islamic teachings that is in accordance with human ability and not burdensome. Fourth, moderate in its method (manhaj). Fifth, moderate in reform and ijtihad. Through wasathiyyah Islam, Indonesian muslims are accustomed to a set of thoughts, behaviors, and actions that promote the spirit of moderation. Moreover, Indonesian Muslims are willing to consciously let go of their primordial religious bonds in favor of moderation. Therefore, waasathiyyah Islam is a concrete realization of a socio-political structure that is deeply rooted since the beginning, not a new diction that is used to describe the mindset of a certain group.
\end{abstract}

Keyword: Wasathiyyah; Moderatism; Inclusive; Muslim Society.

\section{INTRODUCTION}

Socio-religious relationship between Muslims and non-Muslims has been becoming more complex recently. This relationship is not always good. Some issues and misunderstandings often occur. Oftentimes, this issue creates misunderstanding and conflicts that test the social relationship between Muslims and non-Muslims. These conflicts also occur between people from different ethnicities, tribes, races, and groups. After observing this phenomenon, it becomes apparent that the wasathiyah Islam paradigm is one of the most important school of thought in Indonesia. This is in accordance 
with the increase in shift towards far left or far right ideals of Islam among Indonesian Muslims. The shift towards the left extreme gives birth to liberalistic and secular movements in religion, while the shift toward the right extreme allows radicalism and strict fundamentalism in religion to appear.

The issues faced by Muslim society that are caused by radical groups must be addressed immediately. This is the responsibility of all mankind. Moderate Islam should eradicate radicalism and those who support violence in the name of Islam. The concept of wasathiyyah Islam is hoped to be the middle path for the issues faced by muslims. Bringing Islam to the way of wasathiyyah completely is indeed not an easy feat. Apart from the persistent spreading of wasathiyah concept, justice must also be actualized. This is Indonesia's chance to show itself as the largest Muslim country in the world that is also able to combine moderation, democracy, and global cooperation. This is also the appropriate moment for Indonesian muslims to show off Islam's true face and promote it to the whole world.

Many Ulama also agree to uphold wasathiyyah Islamic value as a lifestyle individually and collectively, by putting forward the spirit and values of Islamic civilization history. They become an important part to show the world that all Muslims are practicing the wasathiyyah Islam paradigm in all aspects of life. They also commit to help Muslim countries and communities to take the initiative to promote wasathiyyah Islam paradigm, in the effort to build ummatan wasathan, a just, prosperous, peaceful, inclusive, and harmonious society, based on Islamic teachings and morals.

The work is based on research project employing qualitative method with religious sociological approach. Religious sociological approach is used because the study of al-wasathiyyah concept is tightly related to religion. The basic concept of this sociological perspective concerns the social structure, the construction of human experience, culture, and religion (Berger, 1993, p. 1). Religious sociological approach used in the research is the one created by Emile Durkheim. Because religion has a very significant social function, it is closely related to historical cultural issues that is part of human nature (Durkheim, 1995, p. 62). Therefore, according to Joachim Wach, religion is humanity's response to wards Divine appearance that occurs in men's religious experience (Wach, 1969, p. 10).

The research about the implementation of al-wasathiyyah concept and discourse of moderate Islam is a research field that may uncover the history of Indonesian people's thought and life. As for the steps taken to perform the research are reinterpretation of the studies about wasathiyyah Islam alongside the cultural roots that cause its emergence, as well as examining discourses 
of Islam and moderation in Indonesia. The study is done systematically and objectively by collecting, evaluating, and tasting evidences that support the data and obtaining a strong conclusion. Therefore, the study is holistic in nature by placing the object of the research in an integrated construction (Muhajir, 1994, p. 13).

\section{WASATHIYYAH PARADIGM AND MODERATE ISLAM}

Wasathiyyah Islam is closely related to the muslim society mentioned in AlQur'an as ummatan wasathan. This type of society is able to be the witness of truth for other people (QS. Al-Baqarah: 143). Ummatan wasathan is a society that always maintains its balance, not falling into left extremism or right extremism, and not pulled into radicalism and violence. The word wasathiyyah etymologically can be translated into middle ground and modest. It comes from the Arabic word wasatha which means middle. Therefore, wasathiyyah means to make something to be in the middle (Zakaria, n.d., p. 108). It has similarity with al-tawasuth or al-wasath (moderation), al-qisth (justice), al-tawazun (balance), and al-i'tidal (harmony) (Hilmy, 2013, p. 25). Meanwhile, in English, it can be translated into moderation, mainstream, intermediacy, middle path, midpoint, reasonable, rational, acceptable, and common (Baalbaki \& Baalbaki, 1999). In short, the term wasathiyyah means "moderate attitude", by avoiding or reducing extremism in practicing religion (Bull, 2010, p. 283). The term has two meanings: avoiding extreme behaviors or expressions and having the tendency to choose the middle path (Team $\mathrm{KBBI}, 2014$ ). Al-Waath is a method of thinking, interacting, and behaving in a tawazun (balanced) manner in responding to two situations, so that an attitude suitable with Islamic principles and society's traditions is achieved. In other word, a balance between aqidah, ibadah, and akhlaq is struck (Hanafi, 2013).

The term wasathiyyah also implies justice, which is the key to creating a heterogeneous political society. A just society, which is the main aspiration true muslims trying to actualize, is free of ethnic fanatism, group fanatism, ideological sectarianism, or even religious differences. That's why the principles of wasathiyah Islam is often related to universal religious views, devoid of ideological sectarian barriers. It tends to be more open, tolerant, moderate, and avoid violent methods because it's motivated by the need to achieve justice and common interest. For that reason, the following ayah illustrates the meaning of ummatan wasatha as khaira ummah (the best ummah) (QS. Ali Imran: 110). Allah created muslim community since the Prophet's era up until now as the best community. However, this praise is not absolute and 
permanent. Instead, it depends on the people's willingness to; first, practice wasathiyyah behavior by taking the middle path and being moderat. Second, having the spirit and being consistent in carrying out the task of amar ma'ruf nahi munkar (enjoining good and forbidding evil) (Rahman, 1979).

The significance of ummatan wasathan in the aforementioned ayah is the chosen and just community. In other words, the Islamic community is the best in its religion, morals, and deeds. Allah has blessed them with wisdom, mercy, rightiousness, and kindnes that are not given to any other people. They become the ummatan wasathan, the perfect community that is just and will become the witness for all mankind in the judgement day. Consequently, nearly all tafsir expert state that wasathiyya means the best, the most ideal, the most balanced, and the most proportional (Ibnu Asyur, 1984). One of the main traits of ummatan wasathan is that they strive to practice moderate Islamic values in their life as a believer, a member of the community, and a citizen of the nation. This moderate behavior is the manifestation of the teaching of Islam as rahmatan lil 'alamin; mercy for all creations. The moderate attitude must be preserved to create the best community (Ibnu Asyur, 2001, p. 268). Every Islamic community that implements wasathiyyah Islam is said to have served humanity (shuhadaa 'ala an-naas). With wasathiyya Islam, all muslim communities will become the best communities along with its civil advancements compared to their predecessors.

Wasathiyyah Islam is interpreted as a school of Islam that is accommodating, tolerant, violence-free, and progressive (Bakti, 2005). Therefore, wasathiyyah Islam is the general view of Islam itself that is par eclence, without being dichotomized by sectarianistic interests. Wasthiyyah Islamic attitude is shown by the religious behaviors that avoid violence and extremism. In this context, wasathiyyah Islam is analogous with middle path attituted (tawasut) which is neither extremistic nor fanatic in responding to modern issues. The true significance of wasathiyyah is illustrated by the condition of the community at the time Prophet Muhammad was building Madina with Madina Constitution. The constitution was a document compiled by Prophet Muhammad SAW as a formal agreement between the Islam community with other tribes and significant people in Yathrib (later known as Madina) in 622 AD (Serjeant, 1964: 4). The document was compiled as clearly as possible with the goal of putting the conflict between Bani 'Aus and Bani Khazraj in Madina to an end. For that reason, the document defined several rights and responsibilities of the Muslim, Jewish, and pagan communities in Madina; uniting them into a single community, also known as ummah in Arabic. Madina Constitution also shows that Islam is a religion that brings mercy for all creation. 
Islam is a religion that brings salvation, and at the same time promotes moderate attitude which is neither excessive (ghuluw) nor reckless and indifferent in practicing its teaching. Islam commands us to perform ishlah (improvement and peace) towards mankind, because peace among mankind brings good to the universe (Ibnu Asyur, 1979: 103). There are also ayahs explaining the concept of brotherhood, understanding among each other, being fair, prohibition towards prejudice, insult, evil, hostility, and forcing one's will including forcing one's religion towards others. Wasathiyyah Islam school of thought and movement has some principles including but not limited to: first, being open minded. This is shown by the tolerant, open attitude that regards other group. Islamic teaching has room for everyone so that anyone can see that Islam brings good and mercy for all creation. In realizing this principle, Islamic teaching contains instructions that are constant (tsawabit) in nature and those that are conditional (mutaghayirat) in accordance with the current condition.

Second, justice. The core concept of Islam is tauhid and justice. Justice is the soul of society. Ushul fiqh scholars even consider justice as the main goal of Sharia (maqashid al-syariah). In this context, Islam is more than just a formal religion. Islam is a great treatise of social transformation, liberation, and challenge for personal interests. All Islamic teaching in its essence aims to realize a just society. Third, equality. Islam is at the front line of the fight to bring equality to mankind. Equality describes a condition in which all humans appreciate the commonality of their origin as mankind and commonality in freedom where each of them has reason to think.. Equality is a paradigmatic basis in realizing wasathiyyah Islam's vision. One of the main mission of Islam is to eradicate social systems that are discriminative and exploitative towards the weak.

Fourth, tolerance. Wasathiyya Islam is tolerant and open to differences in vision. This attitude is based on the fact that differences among mankind is a certainty (QS. Al-Kahfi: 29). In accordance with sunnatullah, differences among mankind will always exist. Hence, using force in dakwah towards those with different views, whether in the same religion or not, is not in line with the spirit of mutual respect taught by al-Qur'an. Fifth, liberation. All religions are in essence aim to bring mankind towards prosperity (li mashalih al-ummat). Therefore, religion should be understood productively as a mean of social transformation. Any kind of Islamic discourse should portray religion as gentle and not frightening. This discourse aims to liberate thought, behavior, and ethics which can form social piousness. Therefore, religion should be used as a critical power, not on the contrary, anti-criticism. Sixth, humanity. Since 
its inception, Islam shows that its mission is to build a just society that upholds humane values. In wasathiyyah Islam view, al-Qur'an taught us that mankind in general has been honored by Allah SWT, without differentiating between religion, ethnicity, race, skin color and so forth (QS. Al-Isra: 70).

Seventh, Pluralism. As shown by its name, Islam is a peaceful and peace loving religion. In this peace framework, al-Qur'an views the diversity of religion among mankind as Allah's will, just as Prophet Muhammad was chosen as one Rasul among several that was sent for mankind. The difference in religion is caused by millah differences believed by Islam, Christianity, and Judaism. All those religions come from the same source; God. Eighth, non-discrimination. Since its inception, Islam has firmly opposed oppression, marginalization, and injustice. The exemplary practice of the Prophet in Madinah who created an agreement on equal rights and responsibilities among different ethnic and religious groups shows equality and non-discrimination. This is a central principle in Islamic teaching. Through the principle of equality and non-discrimination among different elements of society, the Prophet built a societal order that is very modern relative to its era.

In certain contexts, the term wasathiyyah is often interpreted as moderatism. However, moderatism itself is difficult to define. It is a highly contested concept both among Muslims or non-Muslims. People understand this concept in different manners, depending on by whom and in what context it is approached and understood (Esposito, 2005: 12). By some group of Islam, the term moderatism is used to refer to a religious practice that disallow violence in solving theological issues in Islam. Because moderatism is relative and can be understood subjectively, it tends to bring controversies and subjective biases (Zainuddin \& Esha, 2016: 63-64). The moderate attitude in religious understanding is a middle path attitude that decisively elaborate religious thoughts that are firmly based on al-Qur'an and hadiths, by establishing ijma' (consensus) of ulama as Islamic scientific treasure and consistently performing ijtihad towards humanity's modern and contemporary issues (Huda, 2010: 178-194).

Muhammad Ali states that moderate Islam are "those who do not share the hard-line visions and actions" (Ali, 2007: 198). He elaborates that moderate Islam in Indonesia refers to Islam communities that put emphasis on normal behavior (tawassuth) in implementing religious teachings that they're trying to establish; tolerant towards differences in views, avoid violence, prioritize thinking and dialogue as their strategy. They are Indonesia's mainstream Islam, even though its strategic movements for modernizing religion and politics are still limited. Ideas such as "Indigenous Islam", "Rational Islam", 
Progressive Islam", “Transformative Islam", "Inclusive Islam”, and “Tolerant Islam" that appear since the 70s can be categorized as part of moderate Islam models in Indonesia. Some ideas of Islam reactualisation, nationalization, and desacralisation of its cultures, or contextual ijtihad can also be included in this category (Ali, 2007: 199).

\section{WASATHIYYAH ISLAM AS THE ROAD TO MODERATISM}

Islam teaches and takes us to follow Allah's way, by using wise manners, good examples, and dialogues (QS. Al-Nahl: 125), and by avoiding hostility and hate caused by differences. This is the concept that should have been applied by the best community among all communities of mankind. Islam always emphasize the importance of respecting and loving each other without differentiating between believes, and prohibits its believers to force their will, let alone using violence in responding to differences in belief. Hence if a Muslim hates others because of their religion, therefore that Muslim is said to have defied Islam's teaching. Wasathiyyah Islam is often interpreted as middle path Islam that is neither extremely fundamental nor extremely liberal. The motto of this genre of Islam is Islam Rahmatan li al'Alamin. Wasathiyyah Islam first appeared in Rasulullah's era, based on the Madinah Charter's articles. The articles can be summarized into five points; First, the relationship between Muslims (ukhuwwah baina al-muslimin). Second, the relationship between Muslims and the Jews, Nasrani, and Sabi'in. Third, nationalism and patriotism of Muslims and non-Muslims to defend the city of Madinah from any threat. Fourth, being alert of any type of infringements that might damage their unity. Fifth, realization of nationalism through security and protection.

The fundamental of Islamic moderation can be seen during Fathu Makkah (the liberation of Mecca) by Rasulullah. He ordered the return of those who had been expelled back to their homes, liberation of an enemy of Islam named Abu Sufyan along with his family, protection of women and children, caring of crops and plants, and prohibition of harassing other religions' worship house. The liberation, protection, and preservation effort done by Rasulullah touched the hearts of Abu Sufyan, his family, and the citizens of Mecca, so that they flock to embrace Islam. The model of Islam offered by Rasulullah as described above is the realization of wasathiyyah Islam and shows Islam as rahmatan li al-alamin. The method is then used as the basis for dakwah strategy done by Wali Songo in transmitting Islamic teachings in Indonesia (Sofiuddin, 2018: 30).

Wasathiyyah Islam has close relation to ethics and moderate tradition that is a form of virtue. In this view, behaviors that are based on the middle path (the 
golden mean) avoid evil and excessive extreme behavior. Moderation tradition in Islam is not limited to a certain aspect of life, but instead include all life aspects, neatly structured in all aspects and spread as wide as life itself. Among the aspects of moderation tradition in wasathiyah Islam are: first, moderate in thought and movement. This can be seen from the belief that is in line with fitrah and ibadah that strives for the prosperity of the world (Ibnu Asyur, 1979: 23). Second, moderate in aqidah. Islamic aqidah (creed) is an aqidah that is compatible with the nature of humanity, in tolerance, consistence, balance, and the difficulty level. Islamic aqidah is free of the deviation of those who state that Allah's hands are tied; those who state that Isa Al-Masih is Allah's son; and those who deny the existence of the ghaib (Al-Qaradhawi, 1981, p. 123). Third, moderate in practicing Islamic teachings. The obligations in Islam are suitable with human's ability and are not burdensome. Islamic teachings do not conflict with life needs. There is time for work to fulfill one's life needs, and there is also time for worship. A leader has the right for privacy while also having to sacrifice himself to lead the people to build the civilization. The moderate attitude in performing Islamic teaching can also be seen in the principles of fiqih. For instance, in fiqh there are the principles of al-masaqqah tajlib al-taysir (difficulties demand ease), al-dharurat tubih al-mahdzurat (emergencies permit the forbidden), and istikab akhaf adh-dhararain (in emergency situation, it is allowed to do something forbidden (haram) with the least disadvantage) (Al-Qaradhawi, 1981: 27).

Fourth, moderate in method (manhaj). Islamic teachings spread to cover all ages and govern all people's life. The correct view of Islam gives birth to the understanding that not all commands in Islam have the same level of urgency. Some of them are obligatory, and others are optional; some are beneficial to many people, others only benefit the doer; some are comprehensive, others are partial. Moderate view dictates us to prioritize obligatory deeds over optional ones; those that benefit many over those with limited benefit; those that are universal over those that are partial. In other word, we should know which one is more important, and then perform and prioritize it over the ones with lower urgency (Al-Qaradhawi, 1981: 61-62). Fifth, moderat attitude in reform and ijtihad. Wasathiyyah is the main character of Islam because it always connects Muslim with their basic principles. Their current living condition is not disconnected from their history, and related closely to the history of the pious generations before them. However, the pious generation of the past had only done ijtihad to solve their contemporary issues. Therefore, we should not burden them with something that is not their business, which is to solve our current issues. In wasathiyyah Islam view, life constantly changes. So, the moderate Islam will not isolate itself from its contemporary era and ignore 
the issues occurring within them. The law must evolve in accordance with the change in situation and condition in every age and region, so that it is always relevant with the sharia of that time without abandoning its correlation with the original law.

Syaikh al-Azhar, also stated that there is a similarity of ethics between Islam and moderation tradition. In his view, the similarity lays on the fact that Islam is situated in the middle, not excessive and not extreme (Al-Thayyib, 2018). Extremism is forbidden in Islam because it is reckless, foolish, and excessive. He further stated that in reality, when someone leave the moderate position and shift towards one extreme, whether it's liberal or radical, it results in division among Islam. Therefore, the concept wasathiyyah is urgently needed to be applied to prevent this divide. The wasathiyyah attitude might be the middle line between two opposing extremes. The middle line is claimed to oppose not only radical view in religion, but also the effort to ignore al-Qur'an as the main source of law. Therefore, the wasathiyyah concept tends to be more tolerant but not too slacked in interpreting the teachings of Islam (Zainuddin \& Esha, 2016: 64).

The moderation tradition built by wasathiyyah Islam can be the solution of the global issues. Global unrest, uncertainty, and the accumulation of global damage, worsened by poverty, illiteracy, injustice, discrimination, and many forms of violence, can be stopped with the implementation of wasathiyyah Islam. Using wasathiyyah Islam, Muslims can be accustomed to a set of thoughts, behaviors, and actions that emphasize the spirit of moderation, and even willing to consciously let go of the primordial ties of its religion. In other word, wasathiyyah Islam is the realization of a socio-political structure that is rooted from the beginning, not a new diction that lately often used to describe the mindset of a certain group.

\section{DISCOURSES OF ISLAM AND MODERATION IN INDONESIA}

All religions are born as social response. They all come from and struggle with social issues. When religion, which is a holy command of God, develops with social issues in mind, it becomes part of history. History, space, and time are the main tests of a religion's truth and robustness. The mediums with which the tests are performed are local cultures, new cultures and phenomena, and rationality. The social context of every region has significant role in forming the people's understanding of moderatism concept. Moreover, the development of a concept always evolve with the advancement of the society in which the concept is understood (Roff, 1987). As the interpretation of the concept is varied, the framework of the application of moderatism is also varied. Various 
social, political, and economic conditions forces it to vary. The same thing also applies to the level of moderation or wasathiyyah. However it is still necessary to strive to achieve the perfect Islam. From this, we may claim that the transformation of Islamic teaching into Indonesian socio-cultural context gives birth to Indonesian Islam that is rich in understanding, interpretation, and appearance. This is in contrast with the condition in Arab where Islam is so rigid toward tradition, culture, and modernity. On the contrary, Indonesian Islam becomes flexible toward traditions, culture, or modernity, as long as they are not threatening and destructive toward the essence of Islam. This also requires the use of some sort of filter to be able to behave in accommodating but also selective manner.

Islam in Indonesia is tolerant and moderate. The diversity and pluralism in Indonesia will always exist by putting importance to unity. In fact, with this condition, Indonesia keeps advancing toward a better future.(30) In his most recent visit to Indonesia, the Vice President of the United States of America, Mike Pence, praised the modern Islam tradition. He also stated that the tradition is very good and inspiring to other nations in the world (Liptak, 2017). This shows that the Indonesian government has succeeded in promoting the identity of the nation as a good face of Islam (Umar, 2016: 399-434). This effort should be maintained, considering that Indonesia has an important role in global politics. The discourse regarding Islamic moderation in Indonesia starts to spread among Muslim groups after the 1998 reformation (Bakti, 2016), and becomes increasingly popular after the Bali Bombings in 2002 (Umar, 2016: 399-434). The discourse encourages Indonesian people to be dynamic and active in promoting rationality, developing open mindedness, and prioritizing common interests over the interest of a certain group (Sholihan, 2008: 53).

Islamic moderation in Indonesia is proven by the convergence and compromise between Islamism, nationalism, and modernism. Even though Islam is the major religion of Indonesia, many Islamic figures who were also involved in the fight for independence support the idea of democracy (republic) instead of Islamic State. The state still pays attention to the development of religion. Even though Muslims comprise the majority of Indonesian population, the idea of Islamic state has always been rejected (Yatim, 2010: 271). This acts as a middle path of ijtihad and historic experimentation that does not pit Islamism with nationalism. Pancasila is a common ground (kalimatun sawa') to accommodate and protect the ethnic and religious diversity of the very plural Nusantaran people. The state always take the middle path and avoid formal religious expression in both domestic and foreign policies, because the state maintain the non-theocratic identity and therefore obliged to reject exclusive 
religious factors (Rizal Sukma, 2010). For Indonesia, moderate Islam is one that is not extreme or radical, that always prevents violence and avoid hard line in implementing its Islam-ness. Liberal Islam or Islamist groups are not considered moderate as long as they don't choose the path of mercy. Therefore, moderate Islam can be identified by the following characteristics: behaving in normal (tawassuth) manner in implementing religious teachings, tolerant towards different views, avoid violence, prioritize dialogue, accommodate modern concepts that are beneficial in its substance, think rationally based on the revelation, interpret nash contextually, use ijtihad in interpreting those that are not stated in al-Quran or Sunnah.

Moderate Islam in Indonesia is an implementation of Islam that is not excessive, especially in religious practice, supports democracy, Pancasila, and NKRI (Unitary State of the Republic of Indonesia). Therefore, the concept of wasathiyyah Islam is very suitable for Indonesia because it is the middle path and moderate way. Indonesia has even implemented the concept of wasathiyah Islam itself. Pancasila, UUD 1945, NKRI, and the motto Bhinneka Tunggal Ika is an implementation of wasathiyyah Islam in Indonesia. Therefore, Islamic moderation in Indonesia comes from the common realization among Muslims instead of enforcement from a ruler or a certain group. With these characteristics, moderate Muslims in Indonesia are those who behave in tolerant, peaceful, and cooperative manner with other religious groups. This is the merciful characteristic of moderate Islam of Indonesia, which is more theological in essence, instead of political such as those devised by the United States when interpreting moderate Islam (Burhani, 2012: 564 - 581).

\section{CONCLUSION}

Thinking in wasathiyah manner and behave moderately in accordance with alQuran is done by consistently follow the guidance taught by Allah through His Prophet and transmitted by the pious ulama. The more we obey and submit to Allah's guidance, the more we should become moderate. This is because Islamic teaching itself has brought its moderate characteristics since it was given to Prophet Muhammad. Those who follow the moderate teachings consistently are worthy to be called ummatan wasathan (moderate community). With this character, wasathiyyah Islam are those who are tolerant, peaceful, and cooperative with those form different religious groups. This is the true nature of Indonesian moderate Islam, which has more of theological significance than political.

Islam wasathiyyah for Indonesia is Islam that is neither extreme nor radical, and do not emphasize on violence or not choose the hard line in implementing 
Islam. Liberal Islam group, or Islamist group, as long as they do not choose the merciful way, are not considered moderate. Therefore, moderate Islam is characterized by normal (tawassuth) behavior in implementing religious teachings; tolerance toward differences in views, avoidance of violence, priority towards dialogue, accommodating towards modern concepts that are beneficial in its substance, rational thinking based on revelation, contextual interpretation of nash, and the use of ijtihad in interpreting issues not covered in al-Qur'an or Sunnah. The implementation of moderate Islam in Indonesia is an implementation of Islam that is not excessive, especially in religious practice, supports democracy, Pancasila, and NKRI.

\section{BIBLIOGRAPHY}

Al-Qaradhawi, Y. (1981). Khashais al-Ammah fi al-Islam. Cairo: Maktabah Wahbah.

Al-Thayyib, S. A.-A. A. (2018). Wasathiyyah al-Islam, li al-Hadharah al-Alamiyyah; at-Tafkir wa at-tathbiq. Jakarta: Maktab al-Mab'uts alKhash li Rais Jumhuriyyah Indunisia li al-Hiwar wa at-Ta’awun baina Mu'taniqy al-Adyan wal al-Hadharah wa ats-Tsaqafah.

Ali, M. (2007). Moderate Islam Movement in Contemporary Indonesia. In R. Sukma \& C. Joewono (Eds.), Islamic Thoughts and Movements in Contemporary Indonesia. Jakarta: Center for Strategic and International Studies.

Baalbaki, M., \& Baalbaki, R. (1999). Al-Mawrid: A Modern Arabic-English Dictionary. Beirut: Dar al-Ilm li al-Malayin.

Bakti, A. F. (2005). Islam and Modernity: Nurcholish Madjid's Interpretation of Civil Society, Pluralism, Secularization, and Democracy. Asian Journal of Social Science, 33(3), 486-505.

Bakti, A. S. (2016). Deradikalisasi Nusantara; Perang Semesta Berbasis Kearifan Lokal Melawan Radikalisasi dan Terorisme. Jakarta.

Berger, P. (1993). The Social Reality of Religion. Hamondsworth: Penguin.

Bull, V. (2010). Oxford Leaners Pocked Diary. Oxford: Oxford University Press.

Burhani, A. N. (2012). Al-Tawassut wa al-I'tidal: The NU and Moderatism in Indonesian Islam. Asian Journal of Social Science, 05(06).

Durkheim, E. (1995). The Elementary Forms of The Religious Life. The Free Press of Glencoe.

Esposito, J. L. (2005). Moderate Muslims: A Mainstream of Modernists, Isla- 
mists, Conservatives, and Traditionalists. American Journal of Islamic Social Sciences, XXII(03).

Hanafi, M. M. (2013). Moderasi Islam: Menangkal Radikalisasi Berbasis Agama. Jakarta: Ikatan Alumni al-Azhar and Pusat Studi Al-Qur'an.

Hilmy, M. (2013). Whither Indonesia's Islamic Moderatism? A Reexamination on the Moderate Vision of Muhammadiyah and NU. Journal of Indonesian Islam, 07(01).

Huda, A. (2010). Epistemologi Gerakan Liberalis, Fundamentalis, dan Moderat Islam di Era Modern. Jurnal de Jure: Jurnal Syariah Dan Hukum, 2(2), 178-194.

Ibnu Asyur, M. al-T. (1979). Ushul an-Nizham al-Ijtima î fi al-Islam. Tunisia: Al-Sharikah al-Tûnisiyyah li al-Tauzî́.

Ibnu Asyur, M. al-T. (1984). Al-Tahrir wa al-Tanwir. Tunisia: Dar AlTunisiyyah.

Ibnu Asyur, M. al-T. (2001). Maqashid al-Syari'ah(II). Yordania: Dar an-Nafa'is.

Liptak, K. (2017). Pence Praises Moderate Islam in Indonesia. 2017, April 20.

Muhajir, N. (1994). Metodologi Penelitian Kualitattif. Yogyakarta: Rieke Sarasin.

Rahman, F. (1979). Islam. New York: The Chicago University Press.

Roff, W. R. (Ed.). (1987). Islam and the Political Economy of Meaning. London \& New York: Routledge.

Serjeant, R. B. (1964). The Constitution of Medina. Islamic Quarterly 8.

Sholihan. (2008). Modernitas Postmodernitas Agama. Semarang: Walisongo Press.

Sofiuddin, S. (2018). Pusaka Kebangsaan: Sinergitas Islam dan Indonesia. Jakarta: Pustaka Compass.

Sukma, R. (2010). Mengelola Paradoks: Identitas, Citra, dan Posisi Internasional Indonesia. Jurnal Analisis CSIS, 39(4).

Team KBBI. (2014). Kamus Besar Bahasa Indonesia Offline Versi 1.5 lansiran 2010-2013 Edisi III. Jakarta: KBBI.

Umar, A. R. M. (2016). A Genealogy of Moderate Islam: Governmentality and Discourses of Islam in Indonesia's Foreign Policy. Jurnal Studia Islamika, 23(3).

Wach, J. (1969). The Comparative Study of Religion. Columbia: The Columbia 
University Press.

Yatim, B. (2010). Sejarah Peradaban Islam. Jakarta: Rajawali Pers.

Zainuddin, M., \& Esha, M. I. (2016). Islam Moderat: Konsepsi, Interpretasi dan Aksi. Malang: UIN Maliki Press.

Zakaria, H. A. bin F. (n.d.). Mu'jam Maqayis al-Lughah (6th ed.). Beirut: Dar al-Kutub al-Ilmiah. 